\title{
A CORRUPÇÃO APRESENTADAS NAS MANIFESTÇÕES DE 2013, REFLETIDA NAS PRODUÇÕES LITERÁRIAS DOS ESTUDANTES DE UMA ESCOLA PÚBLICA NO SUDOESTE BAIANO
}

Valdimir Pereira Reis*

\begin{abstract}
Resumo
O presente trabalho tem o objetivo analisar a corrupção apresentadas nas manifestações de 2013, refletida nas produções literárias dos estudantes de uma escola pública no sudoeste baiano. Neste estudo, tomou-se como objeto de pesquisa a influência das grandes mídias nas produções das narrativas sobre corrupção produzidas nos textos literários dos referidos alunos. Para tanto, nos orientamos nos referenciais de Souza (2016, 2017, 2018, 2019). Este autor afirma que a corrupção do Estado é usada para ocultar a verdadeira corrupção que está no mercado, visto que apontar a corrupção política de forma seletiva foi uma forma de tirar os recursos que beneficiariam as classes populares para direcioná-los para o bolso dos mais ricos. O estudo identificou a existência de um elo de influências entre as vinculações das informações pelas grandes mídias e as composições estudantis. Nos trabalhos analisados a corrupção aparece somente como ação dos agentes políticos do Estado, sem nenhuma referência à corrupção do mercado financeiro ou do poder judiciário. Neste sentido, percebese que os estudantes fizeram apenas a leitura superficial e distorcida, bancada pelos grandes veículos de comunicação. Neste contexto constatou-se que, os estudantes, pertencentes às classes populares, se tornaram vítimas das ideias que reproduziram nos seus textos e consequentemente favoreceu para que a elite do dinheiro se apropriasse dos bens públicos e fomentasse a redução das políticas de inclusão social. Dessa forma, observa-se a importância deste estudo, pois compreender o contexto histórico das produções estudantis no ano de 2013 é de grande relevância uma vez que, nesse ano, os fatos acontecidos deram início às crises que o Brasil enfrenta atualmente: instabilidade política, institucional e a demolição dos direitos e garantias conquistadas pelos trabalhadores ao longo da sua história.
\end{abstract}

Palavras-chave: Manifestações. Produções Literárias. Corrupção. Manipulação.

\footnotetext{
* Mestrando em Ciências da Educação pelo Programa de Postgrado da FICS - Facultad Interamericana de Ciencias Sociales - Assunção - Paraguai. Atua como professor da Educação Básica da Rede Estadual de Ensino no município de Candiba - BA, Brasil. E-mail: valdimir.asa@gmail.com
} 


\section{Introdução}

O presente trabalho apresenta uma discussão sobre a corrupção apresentadas nas manifestações de 2013, refletida nas produções literárias dos estudantes de uma escola pública no sudoeste baiano. A investigação centrou-se no objetivo de identificar os conceitos que influenciaram o pensamento estudantil nas construções dos textos literários, que deram destaque para o tema da corrupção.

Para a realização da pesquisa, fizemos o levantamento bibliográfico dos autores que discutiram as manifestações de 2013 e o tema da corrupção. Adotamos a metodologia baseada numa abordagem qualitativa, que, segundo Gil (2008), privilegia a análise de microprocessos, através do estudo das ações sociais individuais e grupais, realizando um exame intensivo dos dados, tanto em amplitude quanto em profundidade.

Além disso, recorremos à técnica de análise de conteúdo que, segundo Bardin (1977) trabalha a palavra e tenta compreender os participantes ou o ambiente num momento determinado. Como análise que se apoia nesta perspectiva, trabalhamos com as composições estudantis que apresentam um discurso que ocorre dentro de um contexto, buscando desvendar o que está por trás das ideias.

O TAL foi criado pela Secretaria de Educação do Estado da Bahia e começou a ser implantado a partir março de 2009, em toda rede estadual de ensino, e, segundo a Sínteses Dos Projetos Estruturantes - SPE (2015) se tornou o maior projeto de arte literária voltado para a juventude estudantil.

Segundo a SPE (2015) o TAL é composto de três fases: a primeira é interna, ou seja, acontece na escola e o aluno melhor classificado é inscrito para a segunda fase que acontece em nível regional sob a responsabilidade do Núcleo Territorial de Educação (NTE). Este escolhe um para participar do sarau estadual que fica a cargo da Secretaria Estadual de Educação, constituindo assim a terceira etapa.

O estudante tem liberdade para a escolha do tema ou temas a serem tratados na sua produção bem como o gênero textual e gênero literário, ou seja, o aluno não é induzido pelo professor, este deve orientá-lo no sentido de ajudar a melhorar o texto que ele pensou.

O momento da produção dos poemas ocorreu no mês de junho 2013, quando coincidentemente iniciaram os protestos nas capitais e grandes cidades, envolvendo 
principalmente jovens, e ficaram conhecidos como "Jornadas de junho". Protestos estes que repercutiram na grande mídia, o que levou a ter um forte apoio popular.

As Jornadas de junho foram iniciadas pelo Movimento Passe Livre (MPL) que naquele momento lutava contra o aumento de $\mathrm{R} \$ 0,20$ (vinte centavos) na passagem do transporte público na cidade de São Paulo. Segundo Souza (2016), esta pauta municipal é federalizada, por manipulação da grande mídia, que passa a ser contra a PEC 37, contra a corrupção e contra os gastos da copa do mundo para atingir o Governo Federal.

Segundo Souza (2016) a partir dessas manifestações é que começa a formar uma suposta base social para o golpe de 2016 com a construção de uma aliança entre a mídia e a classe média conservadora, que nunca havia aceitado as reformas petistas e sempre votou contra. E paralelamente, a aliança entre a mídia e aparelho jurídico-policial do Estado, principalmente a partir de 2015, passa a deslegitimar o governo, trabalho feito com enorme sucesso pela operação Lava Jato e a Rede Globo. Assim instituições que tinham obrigação de proteger a democracia passam a atacá-la de forma orquestrada para derrubá-la.

Para Souza (2016) as Jornadas de Junho significou a reconstrução da classe média, conservadora, que sempre odiou e desprezou pobre, como ator político já conhecido da sociedade brasileira pela sua participação em golpe, como o de 1964. Assim nos alerta Saviani “[...\} que as nossas classes burguesas são, essencialmente, de perfil autocrático, atuando pela via do golpe e das ditaduras sempre que seus interesses de classe correm algum risco.” (SAVIANI, 2017, p. 54)

Discorre ainda Saviani (2017) que as manifestações de 2013 fez o "ovo da serpente" quebrar-se, de onde saíram cobras do fascismo social e político que se propagou para todo o Brasil, que a partir de então comandou a pauta das ruas, por meio da direita ideológica, que criminalizou o governo Dilma e o PT. “[...]Foi pura ilusão (ou idiotia política) vangloriar as jornadas de junho de 2013 como fez certa suposta esquerda revolucionária." (SAVIANI, 2017, p. 133)

Isto posto, compreender o contexto histórico das produções estudantis no ano de 2013 é de grande relevância uma vez que, nesse ano, os fatos acontecidos deram início às crises que o Brasil enfrenta atualmente: instabilidade política, institucional e a demolição dos direitos e garantias conquistadas pelos trabalhadores ao longo da sua história. 
Neste contexto, Pinto (2017) afirma que houve uma tendência de associar as Jornadas de junho às manifestações ocorridas na Europa, principalmente na Espanha, devido a sua proximidade temporal, pela forma como foram organizadas e pela grande participação dos jovens. Porém nos momentos dos protestos, a Espanha e o Brasil apresentavam situações opostas do ponto de vista econômico. Pinto (2017) aponta que taxa de desemprego no Brasil era de $5,4 \%$, sendo que entre os jovens era de $13,7 \%$, enquanto que na Espanha a taxa de desemprego era de 26,03\% e entre os jovens era 53,7\%. Nesse período, a crise econômica que atingiu a Espanha não tinha chegado ao Brasil.

Neste seguimento o tema do combate à corrupção dominou os noticiários da grande mídia, principalmente a partir do dia 17 de junho 2013. Souza (2016) afirma que as manifestações daquele ano marcaram um ponto de virada da hegemonia ideológica das altas taxas de aprovação aos presidentes petistas, neste período houve uma queda de quase 30 pontos da taxa de aprovação da presidenta Dilma Rousseff e consequentemente iniciou o cerco ideológico contribuindo fortemente pela concretização do golpe de 2016, que tirou do poder a presidenta democraticamente eleita, por meio de um processo de impeachment.

Foi por meio desse material que realizamos a análise do conteúdo das composições dos estudantes, no entanto, não pretendemos discutir a complexidade conceitual do termo corrupção, sua natureza ou sua abrangência, nem a história de sua prática no país. Queremos entender o porquê que os estudantes apresentaram a abordagem que fizeram, tentando perceber as consequências desse entendimento que estão presentes nos textos.

\section{Os agentes políticos na administração do Estado como os únicos responsáveis pela corrupção}

Neste cenário, os alunos acompanharam as manifestações de junho de 2013 por meio da mídia, principalmente via televisão, sendo a Rede Globo a mais assistida, assim alguns estudantes produziram os seus textos literários para participarem do Tempo de Artes Literárias - TAL, projeto estruturante da rede Estadual da Educação da Bahia, com tema da corrupção.

O estudante Citrino escreveu o poema "As verdades do país" que já na estrofe inicial traz o tema da corrupção: 
Estradas e paredes

E cidades paradas

Todos sabem o que aconteceu

Ela foi parada desde quando

A corrupção aconteceu

“As verdades do País" trata das manifestações que ocorreram no mês de junho de 2013, e expressa o desejo de fazer parte deste protesto incentivando os amigos a se engajarem, pois acredita que elas mudarão a situação de corrupção no país e construirão um novo amanhã.

O estudante deixa transparecer que as prestações de serviço estão paralisadas e apresenta que o motivo que levou a esta situação foi quando iniciou a corrupção. Dá a entender que na sua compreensão a corrupção é algo recente, algo que atingiu o Brasil de uma hora para a outra e que impossibilitou ou estancou as atividades laborativas.

Qual a compreensão de corrupção que o estudante traz? O estudante assinala que a causa dos problemas de corrupção e suas consequências têm um culpado que é aquele que exerce o poder político. Apresenta ódio à política, desejando que essa atividade não existisse ou que a partir de então deve despertar o desprezo ou a indiferença das pessoas. Como algo que é marcado pela corrupção, o povo não deve se envolver com ela para não ser considerado um corrupto.

É o que aponta o estudante Citrino na conclusão da sua composição:

\author{
Você culpa o político por tudo \\ Isso é correto \\ São manifestantes como você \\ Que estão certos \\ Assim como você!
}

A estudante Esmeralda com o poema "Brasil, um pais de conquista" também evoca o tema da corrupção: 
A poesia faz uso de algumas expressões do Hino Nacional Brasileiro, inicia-se com a frase "o gigante acordou", numa referência às grandes manifestações de junho de 2013. O "gigante" que está no Hino Nacional que exalta as amplas dimensões físicas e a esperança de grande futuro, é personificado num grande gigante que estava apático, mas que de repente desperta e vai para a rua manifestar, contra a corrupção.

A partir da expressão do Hino Nacional, "deitado eternamente em berço esplêndido", a estudante cria o verso "de um povo que vivia deitado em berço esplêndido" que evoca o sentido que o brasileiro estava adormecido por ter um comportamento pacato e apático, agora se levanta, grita e luta para por fim ao sofrimento.

Manifesta que a partir desses eventos, o povo vai mudar seu comportamento quando estiver diante da "roubalheira e corrupção". Afirma que "nada será como antes", pois uma vez que despertou do seu repouso, estará sempre alerta para reagir perante qualquer situação.

No verso "se verá um brado retumbante" a estudante faz alusão aos versos do Hino Nacional "ouviram do Ipiranga as margens plácidas, de um povo heroico o brado retumbante". Para ela, estas manifestações de 2013 representam o grande grito pela independência do país que irá se livrar da corrupção.

O estudante Rutilo com a composição "acorda Brasil” traz alguns temas das manifestações de 2013, entre eles a corrupção da qual estamos tratando aqui. Pela interpretação influenciada pelas manifestações, essa abordagem se refere apenas à corrupção do agente político do Estado.

O movimento é pelo País,

Contra a PEC 37, contra a impunidade,

Contra a corrupção, contra as tarifas.

Faz uma exaltação às manifestações de 2013 com a expressão “o movimento é pelo país" no sentido que esses protestos que trazem essas pautas vão mudar positivamente a realidade do Brasil, como se esses fossem o ponto de virada para uma vida melhor.

O estudante Rubi com o poema "O povo que paga" aborda a corrupção: 


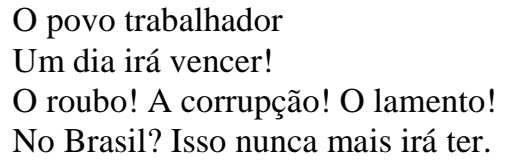

É um poema que afirma que o povo é quem paga por tudo, mesmo sem querer. Vive enganado, quem acha que Brasília tem esplendor, pois lá se rouba sem medo e pudor. No Brasil o roubo, a corrupção nunca mais vai ter, uma vez que o povo trabalhador irá vencer.

$\mathrm{Na}$ análise do estudante "o povo que paga" significa que os recursos públicos, oriundos da arrecadação de impostos, são usados para financiar muitas coisas, mesmo que não queira.

O estudante afirma que o povo trabalhador irá vencer o problema que considera que vem sendo a causa de sofrimento que, em sua análise, é a corrupção. O estudante fala do trabalhador, não como classe social, mas sim como todos que têm uma ocupação. Assim pode ser incluído como trabalhador desde um grande empresário, com grandes capitais econômicos a um diarista que tem apenas a força de trabalho.

Em todas as composições analisadas a corrupção é apresentada como uma ação exclusiva dos agentes políticos na administração do Estado. Mas porque isso acontece? Uma resposta imediata poderia ser devido à influência do tipo de cobertura jornalística das manifestações que abordam essa temática. Mas a resposta dada não é suficiente para abarcar uma explicação adequada ao questionamento.

Para elucidar estas ideias que aparecem nas composições recorreremos a Souza (2009, 2017), que afirma que a ideia que todo brasileiro tem de si mesmo é marcada pela noção de personalismo, pela noção de patrimonialismo e pela noção de populismo. Segundo Souza (2017) esses três conceitos substituem a noção de escravidão e da luta de classes no Brasil.

Além disso, levamos em consideração que os estudantes escreveram livremente e por isso relataram aquilo que acreditam que consideram moralmente correto, portanto, as reportagens que assistiram, tiveram a sua influência facilitada por aquilo que eles já acreditavam, conforme conhecimento adquirido no senso comum.

Neste sentido, a explicação para a forma de pensar dos referidos estudantes está na sua formação enquanto indivíduo dentro de um contexto social, uma vez que, o processo de construção da pessoa começa na família e a escola dá continuidade. Boa parcela da formação 
se concretiza pelo senso comum, que é incorporado pela pessoa sem nenhum questionamento, outra parte vem dos conhecimentos científicos, muitos ensinados pela escola.

Para Souza (2017), a visão que o brasileiro tem de si mesmo é marcada por alguns conceitos criados e propagados pela a escola e sociedade, estes conceitos servem para distorcer a explicação da realidade social em benefício da elite dos proprietários em detrimento dos prejuízos das classes trabalhadores e da ralé dos novos escravos, que fica impedida de construir uma interpretação que poderia contribuir para a sua autonomia, enquanto classes sociais.

Neste sentido, Souza (2017) apresenta os conceitos do patriotismo e personalismo de Sérgio Buarque, este, cria a ideia que todo brasileiro toma decisões levando em conta os interesses pessoais ao invés do interesse público. Suas ações são movidas pelas emoções de ódio ou amizade, por isso tende a ser corrupto. A noção de patrimonialismo, explica-se o comportamento do homem cordial que, ao assumir uma função no Estado, tende a apropriar do bem público como se fosse seu.

Souza (2009) assegura que tanto a noção de personalismo como do patrimonialismo faz parte do conhecimento do senso comum como também do conhecimento científico. Sendo assim, os estudantes que fizeram os seus poemas que tratam da corrupção são influenciados desde a sua formação inicial, no convívio com a família e a sociedade até os conhecimentos adquiridos na escola.

Desse modo "o trabalho de distorção sistemática da realidade realizado pela mídia foi extremamente facilitado pelo trabalho prévio de intelectuais que forjaram a visão dominante" (SOUZA, 2017, p. 14). Este fato, explica o tipo de cobertura jornalística tendenciosa, apresentando a corrupção de maneira seletiva, realizado pela grande mídia ter reverberado de forma tão incisiva no pensamento dos estudantes.

Mas, para que fim serve os brasileiros acreditarem na noção de personalismo e do patrimonialismo? Porque estas noções estão presentes tanto no senso comum como nos conhecimentos científicos ensinados na universidade? Por que elas se tornaram dominantes? Na percepção de Souza (2017) serve para a elite do dinheiro silenciar a semente escravista e esconder a análise das classes sociais e suas lutas substituindo por uma interpretação conservadora e cientificamente falsa. 
Em outras palavras, serve para a elite do dinheiro dominar todas as outras classes, colocando-as ao seu serviço. Souza (2017) discorre que a ideia do patrimonialismo impediu qualquer percepção crítica do Brasil e a elite do dinheiro conseguiu controlar todas as frações da classe média e permitiu o seu acúmulo de riquezas em detrimento da continuidade da desigualdade e da injustiça social.

O tema da corrupção nos poemas dos estudantes é diretamente influenciado pelas manifestações de junho de 2013. Mas porque a corrupção aparece como um grande problema nestes protestos? Quais objetivos eles servem?

Na concepção de Souza (2017) o tema da corrupção, sempre apresentada como sendo apenas do agente do Estado é um instrumento de que a elite do dinheiro faz uso, principalmente para duas situações específicas. A primeira situação, a corrupção é uma carta na manga para fazer o ataque à soberania popular, quando esta coloca no poder político alguém que vai contra aos interesses econômicos da elite do dinheiro. Nesse sentido, em 2013 essa elite queria por fim aos governos petistas, para isso o caminho mais fácil foi apontar a corrupção, apenas do Estado, de maneira seletiva de tal forma que atinja somente aos alvos de seu interesse.

A segunda situação, continua Souza (2017) que a ideia de corrupção serve para a elite do dinheiro apropriar-se com o preço baixo, das empresas estatais e das riquezas do subsolo que deveriam ser revertidas em benefício de todos. A corrupção do Estado é usada para ocultar a verdadeira corrupção que está no mercado. Falando com outras palavras, apontar a corrupção política de forma seletiva foi uma forma de tirar os recursos que beneficiariam as classes populares para direcioná-los para o bolso dos mais ricos. “[...]A denúncia de corrupção aparece ciclicamente em nossa história, sempre que é necessário ou conveniente às elites dominantes, com o endosso do judiciário e o uso das forças repressivas do Estado burguês. (SAVIANI, 2017, p. 4)

Para Souza (2017) a elite real, que está fora do Estado faz a sua captura, mas a ideia é distorcida para que se perceba a corrupção apenas dos políticos. Ele faz uma analogia afirmando que o combate à corrupção só dos agentes políticos seria como se fosse combater o narcotráfico pegando apenas os "aviõezinhos". Acrescenta Saviani (2017) que ser corrupta é uma característica básica da burguesia como classe social que busca obter a máxima lucratividade e realizar os melhores negócios. Dessa forma, deixa de fora a elite do dinheiro 
que faz toda rapinagem. "É uma ideia que nos imbeciliza, já que desloca e distorce toda a origem do poder real". (SOUZA, 2017, P. 13)

Nas composições dos estudantes a corrupção tratada é apenas a dos agentes políticos do Estado, sem nenhuma referência à corrupção do mercado financeiro ou do poder judiciário. Pelo que é possível verificar, os estudantes fizeram apenas a leitura superficial e distorcida, bancada pelos grandes veículos de comunicação. Como nos aponta Souza (2017) essa interpretação foi realizada para tornar invisível a grande corrupção do mercado, que apropria do patrimônio público.

Como pertencentes às classes populares, os estudantes se tornaram vítimas dessas ideias que reproduziram nos seus textos, porque favoreceu que a elite do dinheiro se apropriasse dos bens públicos em detrimento às perdas que tiveram, com a venda do patrimônio público a preço vil, da retirada de direitos e a redução das políticas de inclusão social.

Souza (2017) nos assinala que a elite do dinheiro para fazer a sua dominação compra todas as outras elites. Depois de comprar a elite intelectual, compra a elite política, por meio do financiamento de suas campanhas. Em seguida compra direta ou indiretamente a elite jurídica, jornalística e literária. Portanto a corrupção é uma prática corriqueira da elite do dinheiro, mas não é publicada, ao contrário é invisibilizada. Nos chama atenção Saviani (2017), que o capitalista, no seu intuito de acumulação, não tem qualquer limite, seja econômico, político, social, ético ou moral.

A narrativa da corrupção política que iniciou com as manifestações de 2013 e continuou até 2016 foi responsável pelo golpe de 2016, que tirou do poder uma presidente democraticamente eleita. Tal fato gerou diversas consequências desastrosas para a população, especialmente, mais pobres.

Para entender o golpe de 2016 ocorrido no Brasil, segundo Saviani (2017) não pode levar em consideração apenas as disputas políticas entre os partidos PT, PMDB e PSDB, mas “[...]as articulações sinistras entre Congresso Nacional, Supremo Tribunal Federal, Procuradoria Geral da República, Ministério Público Federal e Polícia Federal no seio do aparelho de Estado, ao lado da Operação Lava-Jato e a intensa manipulação da opinião pública pelo Grande Imprensa, com destaque para a TV Globo.”( SAVIANI, 2017, p. 138) 
A Operação Lava-Jato é uma operação de investigação, constituída de uma forçatarefa que participa o Ministério Público Federal e Polícia Federal para denunciar a corrupção entre políticos e empresas brasileiras, que são julgadas pela Justiça Federal. Assim, como juiz dessa operação, aponta Saviani (2017), que Sérgio Moro passou a ser a máquina de guerra para fazer a provocação para que a direita fisiológica e mafiosa de aliasse com a direita neoliberal e o Dep. Eduardo Cunha encaminhasse o pedido e impeachment da Presidente Dilma.

Saviani (2017) assinala ainda que a partir do momento que o PT assumiu o governo federal passou a ser alvo de ataques dos setores conservadores e reacionários da sociedade brasileira. Neste contexto, a Operação Lava-Jato se insere como uma articulação do Poder Judiciário que se associa a grande mídia antipetista. Neste sentido, Saviani (2017) conclui que a Operação Lava-Jato cumpriu duas tarefas principais: provocar a instabilidade para o golpe 2016 e tirar o presidente Lula da corrida presidencial.

Com a articulação dessas instituições, aponta Saviani (2017) que o golpe ocorreu com aparência legal e constitucional, porque o impeachment está previsto na Constituição. Mas o crime de responsabilidade da presidente, única condição que o impeachment ocorra não foi tipificado, por isso a sua realização foi um golpe, que rompeu todas as garantias constitucionais.

Na análise de Saviani (2017), a contrarrevolução, um conceito de Florestan Fernandes, é a categoria que melhor explica os diversos golpes no Brasil, como uma reação conservadora diante dos tímidos ganhos da classe trabalhadora A contrarrevolução apresenta as característas: anti-democráticos, antipopulares, anticomunistas, antinacionais e próimperialista. Saviani (2017) aponta que “[...] a única forma de impedir os golpes, venham como ele vier, é através da organização e resistência popular.” (SAVIANI, 2017,p. 54)

O golpe de 2016 abre o caminho para o vice-presidente Michel Temer assumir o governo. Souza (2019) indica que logo que assume o governo, Michel Temer passa a vender o patrimônio nacional e faz a reforma trabalhista que precariza as condições de trabalho, além disso fomenta o aumento da taxa do desemprego, empobrecimento geral da população e o abandono dos serviços públicos.

Para Souza (2019), a narrativa da corrupção apenas da classe política foi um "bode expiatório" para invisibilizar o roubo, mil vezes maior, da elite dos proprietários sob o 
comando do rentismo, disfarçada de legalidade. Assim, meia dúzia de estrangeiros e seus capangas brasileiros tornaram-se donos do petróleo e outros recursos nacionais. Desse modo, a população viu os combustíveis e o gás de cozinha dobrarem de preços e o seu poder de compras ser reduzido, devido a elevação dos custos de vida e a consequente aumento da pobreza.

Souza (2019) aponta que no contexto de combate a corrupção política, os rentistas, pelo processo de dominação simbólica, explora a classe média, que acabam por dar vazão ao ódio aos pobres, dessa maneira, a classe média, as suas facções mais conservadora, quer “[...] que o povo continue como sempre foi: pobre, humilhado e obediente". (SOUZA, 2019, p. 251)

O referido autor ainda afirma que além de ganhar mais que os pobres, a classe média não quer pobres nas universidades, competindo pelos mesmos empregos, usar o mesmo avião, comprar a mesma roupa e perder a empregada doméstica. Além disso, a classe média tem o prazer sádico "[...] do senhor de escravos: o gozo da humilhação contra quem não tem defesa e precisa aturar calado a piada, o abuso, o insulto, a humilhação sob todas suas formas". (SOUZA, 2019, p. 251)

Com a narrativa de combate à corrupção, grande mídia usou a classe média conservadora como tropa de choque, ocupando as ruas para ser a falsa base social para atingir seus objetivos para o golpe. "[...]O Partido da Imprensa Golpista (PIG), tendo como vanguarda midiática a TV Globo, utilizou-se do discurso de combate sensacionalista à corrupção, seduzindo uma 'classe média' historicamente idiota na política, e liberal na visão de mundo. (SAVIANI, 2017, p. 135)

Neste contexto, o representante político responsável pela ascensão dos mais pobres, o ex-presidente Lula herda o ódio da classe média. A narrativa da corrupção política cria o clima de que a pobreza é fruto exclusivo da corrupção política, por isso o sistema político é deslegitimado. Para a resolução das questões da corrupção "[...] o golpe de misericórdia foi a prisão injusta do líder das classes populares desmobilizadas”. (SOUZA, 2019, p. 254)

Preso, o ex-presidente Lula foi impedido de participar das eleições de 2018 e a partir desse fato abriu as portas para a eleição de Jair Bolsonaro, “[...] defensor da ditadura militar, do racismo, da tortura e do assassinato de opositores como arma política”. (SOUZA, 2019, p. 
Como nos apresenta Souza (2019) esse suposto combate a corrupção, a criminalização seletiva da política serve para “[...] tornar o orçamento do Estado um banco particular da elite; criminalizar sob todas as formas a soberania popular." (SOUZA, 2019, p. 258). Assim a elite torna invisível a corrupção legalizada do mercado e cria as condições para tirar do poder governos populares.

A operação "Lava Jato", agindo em parceria com a grande mídia, foi responsável por tornar essa narrativa de combate à corrupção como uma novela presente todos os dias na vida do brasileiro. Com o objetivo de usar a mesma tática, no dia 04 de março de 2019 o presidente Jair Bolsonaro anunciou a criação da "Lava Jato da Educação", para investigar dinheiro investido na Educação nos anos anteriores ao seu mandato. Sob a coordenação dos então ministros, Sérgio Moro, da Justiça, e Ricardo Vélez, da Educação, pretendem apurar indícios de corrupção no MEC.

Pelo que representou a narrativa de combate à corrupção, iniciada em 2013 que foi a retirada de direitos dos trabalhadores, a entrega do patrimônio público a baixo custo para a iniciativa privada, o que podemos esperar desta "lava Jato da Educação" será a retirada de direitos dos mais pobres que tiveram acesso à educação superior, principalmente pelo recebimento de bolsa para permanecer nas universidades, por um lado serão iniciados um processo de perseguição e criminalização de das lideranças politicas e educadores que foram responsáveis pela inclusão desta política pública. Após isso, essas políticas públicas serão extintas, como forma de estancar a corrupção.

Assim como a narrativa de combate à corrupção cimentou o caminho, para o Golpe de 2016, para fazer a privatização do patrimônio público e a eleição de Bolsonaro, a narrativa da "Lava Jato da Educação" irá construir será para a privatização das Universidades Públicas e entrega-las ao capital nacional e estrangeiro.

Ao questionarmos o que fazer para enfrentar esta situação, nos recorremos a Freire (1897) que afirma que o objetivo dos opressores é dominar os oprimidos pela forma de pensar. "Em todas as épocas os dominadores foram sempre assim - jamais permitiram às massas que pensassem certo" (FREIRE, 1987, p. 74). Usam a manipulação para anestesiar as camadas populares, impedindo que elas pensem.

Por meio da manipulação da forma de pensar, os opressores mantêm os oprimidos sob o seu domínio. Feire (1987) assinala a manipulação como uma necessidade das elites para 
impedir que as massas populares se organizem e surjam como sujeitos da sua libertação. Nesse sentido Souza (2017) indica a noção de patrimonialismo e, por consequência, a corrupção foi usada pela elite do dinheiro para fazer a manipulação de todas outras classes, impedindo que elas pudessem pensar certo ou pensassem como o opressor.

Freire (1987) nota que quanto mais imaturas politicamente as massas populares, mais fáceis são de manipular, além disso, ficam conformadas e atendem os objetivos dos opressores, que perpetuam os seus poderes.

Dessa maneira, percebemos que a forma de pensar dos estudantes sobre o tema corrupção, traz a marca da manipulação realizada pela elite dos proprietários. Essa manipulação impediu que os estudantes pudessem construir o pensamento adequado, que contribuíssem para a sua autonomia e pensassem como a elite dos proprietários e a classe média que desejavam a sua dominação.

A manipulação visa à opressão. "A opressão, que é um controle esmagador, é necrófila. Nutre-se do amor à morte e não do amor à vida" (FREIRE, 1987, p.37). Sua ação inibe o poder do homem de criar e de atuar como sujeitos de sua ação.

Freire (1987) traz a reflexão da ação antidialógica e classifica-a como opressora, que tem o objetivo de dominar. Esta serve para anestesiar, impedindo que as massas populares pensem. Ela mitifica a realidade, promovendo o sectarismo e o irracionalismo e cria obstáculo para a transformação da realidade.

A ação antidialógica apontada por Freire (1987) desenvolve a educação bancária, que consiste em depositar, transferir e transmitir o conteúdo programático elaborado pelo educador. Nesta visão, o educador é aquele que sabe e que doa seus conhecimentos para aqueles que não sabem, os educandos. Assim, o poder de criatividade do educando é inibido para desenvolver a ingenuidade e a não criticidade, para satisfazer o poder do opressor.

Freire (1987) indica as saídas para a superação desta situação de opressão. Ele nos chama atenção de que é verdadeiro que uma pessoa pode oprimir a outra, porém "já não se pode afirmar que alguém liberta alguém, ou que alguém se liberta sozinho, mas que os homens se libertam em comunhão" (FREIRE, 1987, p. 75). Dessa forma Freire (1987) se opõe ao pensamento das elites dominadoras que coloca a libertação no êxito pessoal. 
Este autor, afirma que a libertação dos homens acontece pela ação dialógica de uma educação problematizadora, que não pratica o ato de depositar, transferir ou transmitir valores e conhecimentos, mas que rompe os métodos da educação bancária desmitificando a realidade para criar as condições de conhecimento.

A educação problematizadora é comprometida com a libertação, tendo o diálogo como algo imprescindível da ação libertadora e transformadora dos homens. Ela serve para a organização das massas populares, para promover a união e o desdobramento dessa união, já que os sujeitos transformam o mundo em colaboração. Sua ação é humanizadora.

Freire (1987) é categórico ao afirmar que a educação problematizadora é o antídoto para a superação de todas as formas de manipulação. A educação problematizadora não está em oferecer um conteúdo revolucionário, mas na problematização da realidade. Significa não aceitar passivamente as interpretações que são apresentadas.

Neste sentido, a consciência de classe é indispensável para a realização da revolução. É ela que vai possibilitar que os oprimidos se unam e se libertem em comunhão com os outros. A consciência de classe é o pensar certo para fazer frente à manipulação da elite opressora.

No entanto, no atual conjuntura política e social, a luta de classes é sistematicamente silenciada como forma de manipulação das classes populares, porque ela seria importante para compreender como a injustiça e a desigualdade é produzida. Ela seria a ferramenta para o entendimento de tudo que é importante na sociedade, Souza (2017)

A luta de classes é o que parece evidente. A elite do dinheiro deseja manter os seus privilégios e a concentração da riqueza nacional. Para isso, ela tem que manter todas aos outras classes sob seu domínio. Mas como pode uma elite tão pequena reprimir toda uma população e por longo tempo?

Para Souza (2016) qualquer um que deseja dominar economicamente o outro precisa antes de tudo dominar o seu espírito, pois a violência, além de ser custosa, o seu resultado é de curta duração, pois a vítima vai reagir sempre. Assim o explorador vai convencer o explorado de que esse acontecimento é para o seu próprio bem.

Assinala ainda, que a luta de classe vai além da disputa pelos capitais, tem também a disputa pelas narrativas para se colocar como dominantes através das interpretações que 
legitimam e justificam as posições alcançadas. A grande mídia é o instrumento, nas mãos da elite dos proprietários, para fazer a divulgação das suas interpretações.

Assim, a abordagem que os estudantes construíram sobre o tema da corrupção espelha a luta de classe, ou seja, a manipulação que a elite do dinheiro realiza para que as classes populares defendam não os interesses próprios, mas os interesses dessa elite. Contudo, essa luta de classe é ocultada sistematicamente para facilitar o domínio da elite dos proprietários.

Para Freire (1987) é necessário que as massas populares tenham consciência de classe e Souza $(2016,2017)$ aponta que as classes sociais estão em luta. Saber disso ou não implicará em pensar certo e se posicionar a favor de si mesmo ou contra si mesmo. Significa saber com quem se une e que interesses defendem. Quando esta percepção é distorcida e o indivíduo se junta com o seu opressor, termina por oferecer as suas forças que voltarão contra si.

Após analises das produções dos estudantes, percebemos que não demonstram ter consciência de classe e nem de que as classes estão em luta. Ao contrário, deixam transparecer a visão de que a população se encontra na mesma situação, sem qualquer conflito de interesse das classes sociais e que todos buscam objetivos comuns. Por essa falta de consciência terminaram por se posicionar e oferecer suas forças em favor da elite dos proprietários e da classe média.

Por falta da consciência de classe e suas lutas, os estudantes foram vítimas da violência simbólica ao fazer a defesa da corrupção, que a elite dos proprietários e a classe média apontavam de maneira seletiva, que serviram para tirar direitos das classes populares e os donos do dinheiro aumentar os seus capitais, como nos assinala Souza (2017).

Esta visão de corrupção que teve a base teórica em Sergio Buarque serviu para garantir a apropriação indevida feita pelo mercado financeiro. "Essa legitimação tem de esconder o mundo social injusto como ele é e também, se possível, ainda deslocar a atenção para aspectos falsamente importantes - ou, pelo menos, de importância secundária com relação às questões mais importantes". (SOUZA, 2017, P. 109)

Norteados por essa interpretação de Souza (2017) e Freire (1987) entendemos que a visão dos estudantes sobre a corrupção foi deslocada para ocultar outros problemas mais importantes, como por exemplo, a desigualdade social e a realidade social não foi problematizada para que pudesse construir um pensamento que levasse à sua autonomia. 
Toda distorção é feita para dominar as classes populares. Souza (2017) nos assegura que a classe média sempre foi a tropa de choque da elite dos proprietários, mas essa dominação é simbólica, pois é realizada pelo convencimento das ideias. Assim, a classe média exerce a autoridade em nome dos mais ricos, já que a elite dos proprietários é bem pequena. Nos dias de hoje, a classe média faz o mesmo papel que exercia o capitão do mato na época da escravidão.

Indica-nos Souza (2017) que assim como a elite dos proprietários concentra o capital econômico, também a classe média exerce o controle sobre o capital cultural e que seu discurso moralista contra a corrupção e sua participação em golpes têm a ver com a proteção desse capital cultural como sendo exclusivamente seu.

Nos alerta Souza (2017) que para compreender a sociedade brasileira atual temos que analisar o papel da grande mídia conservadora, pois ela desempenha a ação central como instrumento de dominação. Hoje essa mídia faz a mesma função que faziam os exércitos de cangaceiros a serviço da elite dos proprietários. Essa dominação nos dias de hoje é exercida pela colonização das consciências e não pelo uso da violência física, como faziam os cangaceiros. Portanto, a violência física foi substituída pela violência simbólica que é igualmente cruel, porém é mais eficiente por não ser percebida facilmente.

Ademais, essa dominação realizada por meio da grande mídia acontece por ter aqui no Brasil uma imprensa totalmente desregulada, que faz uma interpretação da vida social totalmente distorcida e motivada por interesse antipopular. Essa mídia não mostra a diversidade de opiniões que possibilitasse a reflexão e o exercício da democracia. "Isso equivale a imbecilizar uma nação que certamente não nasceu imbecil, mas foi tornada imbecil para os fins comerciais de uma única família que representa e expressa o pior de nossa elite do saque e da rapina". (Souza, 2017, p. 124)

Souza (2017) chama de corrupção dos tolos, a corrupção apenas estatal, sem levar em conta a corrupção do mercado financeiro, narrativa feita pela mídia que transformou o cidadão em um imbecil, e por isso, fica fácil convencê-lo de que uma empresa estatal como a PETROBRÁS deve ser privatizada porque foi dominada por corruptos.

\section{Conclusão}


A análise realizada neste trabalho, aponta que as produções dos estudantes foram fortemente marcadas pelo tipo de cobertura realizada pela grande mídia, e pelos conceitos de personalismo e patriotismo inculcados durante toda sua formação pessoal e estudantil.

Neste sentido, os estudantes não demonstram a consciência de classe e nem de que as classes estão em luta. Ao contrário, deixa transparecer a visão de que a população se encontra na mesma situação, sem qualquer conflito de interesse das classes sociais e que todos buscam objetivos comuns. Por essa falta de consciência terminaram por se posicionar e oferecer suas forças em favor da elite dos proprietários e da classe média.

Percebemos que apesar das Jornadas de Junho ter sido de abrangência municipal elas foram federalizadas, e a cobertura jornalística foi distorcidas para atingir o Governo Federal e consequentemente chegou aos alunos e suas percepções por meio das produções literárias. Assim, os textos dos estudantes abordam a corrupção apenas de forma genérica, sem fazer a particularização seletiva, que a mídia vinha realizando. Ou seja, neles não aparece nominalmente a presidente Dilma, o que pode ser interpretado que os alunos estavam fazendo a aprovação do seu governo, devido às políticas sociais até então desenvolvida.

Outro fator analisado foi que as manifestações apareceram na grande mídia de forma surpreendente e as produções foram realizadas neste contexto, a interpretação do momento torna mais difícil devido ao fato de o período não ter permitido maiores reflexões como acontece a partir do distanciamento temporal.

Neste contexto, podemos inferir se os estudantes já possuíssem uma consciência de classe e tivesse recebendo uma educação dentro de uma ação problematizadora como nos ensina Freire ( 1987) eles teriam os instrumentos cognitivos para fazer um posicionamento interpretativo que servisse de antídoto às ideias da elite dos proprietários e da classe média que buscavam dominação. A educação problematizadora seria o caminho para a superação de uma consciência ingênua e acrítica.

Após analise das produções dos estudantes, percebemos que os referidos alunos não demonstram ter consciência de classe e nem de que as classes estão em luta. Ao contrário, deixa transparecer a visão de que a população se encontra na mesma situação, sem qualquer conflito de interesse das classes sociais e que todos buscam objetivos comuns. Por essa falta de consciência terminaram por se posicionar e oferecer suas forças em favor da elite dos 
proprietários e da classe média e reproduzir sem questionar o que as grandes mídias os oferecem.

\section{Referências}

BAHIA. Síntese dos Projetos Estruturantes. Bahia: Secretaria de Educação do Estado da Bahia/Jornada Pedagógica 2015.

BARDIN, Lawrence. Análise de Conteúdo. Lisboa: Edições 70, 1977.

FREIRE, Paulo. Pedagogia do Oprimido. 17. ed. Rio de Janeiro: Paz e Terra, 1987.

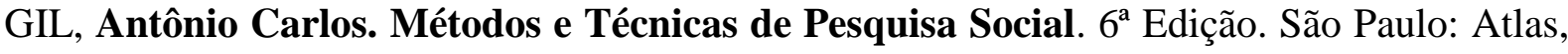
2008.

PINTO, Céli Regina Jardim. A Trajetória Discursiva das Manifestações de Rua no Brasil. Lua Nova: Revista de Cultura e Política. São Paulo, fev-2017.

SAVIANI, Dermeval. A crise política no Brasil, o golpe e o papel da educação na resistência e na transformação. IN: LUCENA, Carlos; PREVITALI, Fabiane Santana; LUCENA, Lurdes (Org). A crise da democracia brasileira. V. I, Uberlândia: Navegando Publicações, 2017.

SOUZA, Jessé. A Ralé Brasileira: Quem São e Como Vive. $1^{\text {a }}$. Ed. Belo Horizonte: Editora UFMG, 2009.

SOUZA, Jessé. A Elite do Atraso: da Escravidão à Lava Jato. $1^{\text {a }}$. Ed. Rio de janeiro: Leya, 2017.

SOUZA, Jessé. A radiografia do Golpe: entenda como e porque você foi enganado. $1^{\text {a }}$. Ed. Rio de janeiro: Leya, 2016.

SOUZA, Jessé. A Elite do Atraso: da Escravidão a Bolsonaro. $1^{\text {a }}$. Ed. Rio de janeiro: Estação Brasil, 2019. 